\title{
Effects of Inoculation of Rhizobium on Nodulation and Nitrogen Accumulation in Cowpea Subjected to Water Availabilities
}

\author{
Salomão Lima Guimarães*, Edna Maria Bonfim-Silva, Julio Cezar Fornazier Moreira, \\ Christiane Kamila Bosa, Samara Lorâine Soares da Silva, Tonny José Araújo da Silva \\ Department of Agricultural and Environmental Engineering, Institute of Agricultural Sciences and Technology, \\ Federal University of Mato Grosso, Rondonópolis, Brazil \\ Email: 'slguimaraes@ufmt.br
}

Received 6 May 2015; accepted 8 June 2015; published 11 June 2015

Copyright (C) 2015 by authors and Scientific Research Publishing Inc.

This work is licensed under the Creative Commons Attribution International License (CC BY). http://creativecommons.org/licenses/by/4.0/

(c) () Open Access

\begin{abstract}
With high protein content, the cowpea is one of the most widely consumed legumes in northeastern Brazil. This study was aimed to evaluate the rhizobia inoculation effect on nitrogen accumulation and nodulation in cowpea subjected to water availability. The experiment was conducted in a greenhouse, in a completely randomized design, with six water availabilities $(40 \%, 60 \%, 80 \%$, $100 \%, 120 \%$ and $140 \%$ of maximum soil water retention capacity), with four replications. Soil moisture maintenance was performed by gravimetric method. The BR3267 strain (Bradyrhizobium japonicum) recommended for cowpea grown in Brazil was used. At thirty-five days after treatments implementation, the nitrogen nutritional status was assessed through SPAD reading, shoot nitrogen concentration and total accumulation. Nodulation was assessed by nodules number and dry matter. The increased water availability provided negative effect on SPAD reading and shoots nitrogen concentration. Shoot nitrogen accumulation was favored to up to $78.8 \%$ water availability, with subsequent decline. Nodulation was favored when soil water availability was between $85 \%$ and $87 \%$. Water availability affects nodulation and cowpea nutritional status, although negative effects are more pronounced when there is soil water excess.
\end{abstract}

\section{Keywords}

Vigna unguiculata, Inoculant, Simbiosis, Water

\footnotetext{
${ }^{*}$ Corresponding author.
}

How to cite this paper: Guimarães, S.L., Bonfim-Silva, E.M., Moreira, J.C.F., Bosa, C.K., da Silva, S.L.S. and da Silva, T.J.A. (2015) Effects of Inoculation of Rhizobium on Nodulation and Nitrogen Accumulation in Cowpea Subjected to Water Availabilities. American Journal of Plant Sciences, 6, 1378-1384. http://dx.doi.org/10.4236/ajps.2015.69137 


\section{Introduction}

Cowpea (Vigna unguiculata (L.) Walp.) is a rustic species which is well-adapted to tropical regions climate and soil conditions, having high genetic variability, thus being used in different production systems [1].

In Brazil, cowpea bean production is concentrated in the northeastern and northern regions. However, this culture has been cultivated in the midwest region, due to the development of cultivars with features that allow mechanization [2].

Nitrogen is one of the nutrients required in highest quantity by cowpea. As for being a legume species, it conducts biological nitrogen fixation (BNF) when associated with nitrogen-fixing bacteria [3].

Thus, when effectively nodulated by efficient strains, it can dispense other nitrogen sources, and through FBN, achieve high productivity levels [4]. According to reference [5], the inoculation of cowpea plants has shown gains not only in the increase of dry matter, but also in total nitrogen and nodulation, confirming the importance of symbiosis between bacteria and cowpea, thus generating productivity gains. However, nodulation and BNF may be influenced by factors that can maximize or minimize the process including soil water availability.

Water is the most important factor in crops development and production, since virtually all plant physiological processes are influenced by soil available water amount. Water deficit is one of the most limiting factors for cowpea development [6]. In contrast, soil water excess promotes $\mathrm{O}_{2}$ deficiency and $\mathrm{CO}_{2}$, methane, ethylene and hydrogen sulfide accumulation, thereby reducing aerobic respiration [7].

Plant physiological processes are affected under water stress, including absorption and biological nitrogen fixation, causing nodules mass, shoot growth and cowpea crop nitrogen concentration decrease [8].

Water importance for plant growth is clear. Thus, this study aimed to assess cowpea plants nodulation and nutritional status under water availabilities.

\section{Material and Methods}

The experiment was conducted in a greenhouse, in $8 \mathrm{dm}^{3}$ pots containing screened dystrophic red Latosol in 4 mm sieve, collected at $0-0.20 \mathrm{~m}$ depth layer. Soil chemical and physical characterization was conducted in accordance with [9], giving $\mathrm{pH}\left(\mathrm{CaCl}_{2}\right): 4.1 ; \mathrm{P}\left(\mathrm{mg} \cdot \mathrm{dm}^{-3}\right)=2.4 ; \mathrm{K}\left(\mathrm{mg} \cdot \mathrm{dm}^{-3}\right)=28 ; \mathrm{Ca}\left(\mathrm{cmol}_{c} \cdot \mathrm{dm}^{-3}\right)=0.3 ; \mathrm{Mg}^{-}$ $\left(\mathrm{cmol}_{\mathrm{C}} \cdot \mathrm{dm}^{-3}\right)=0.2 ; \mathrm{H}\left(\mathrm{cmol}_{\mathrm{C}} \cdot \mathrm{dm}^{-3}\right)=4.2 ; \mathrm{Al}\left(\mathrm{cmol}_{\mathrm{C}} \cdot \mathrm{dm}^{-3}\right)=1.1 ; \mathrm{SB}\left(\mathrm{cmol}_{\mathrm{c}} \cdot \mathrm{dm}^{-3}\right)=0.6 ; \mathrm{CTC}\left(\mathrm{cmol}_{\mathrm{C}} \cdot \mathrm{dm}^{-3}\right)=$ 5.9; V $(\%)=9.8$; Organic matter $\left(\mathrm{g} \cdot \mathrm{dm}^{-3}\right)=22.7$; Sand $\left(\mathrm{g} \cdot \mathrm{kg}^{-1}\right)=549 ;$ Silt $\left(\mathrm{g} \cdot \mathrm{kg}^{-1}\right)=84$; Clay $\left(\mathrm{g} \cdot \mathrm{kg}^{-1}\right)=367$.

Soil correction was performed through base saturation method, raising it to $60 \%$ level, with dolomitic limestone incorporation (PRNT $=80.3 \%)$. After merging with limestone, soil samples were moistened to field capacity and incubated for 30 days.

The experimental design was completely randomized, with five water availabilities (40\%, 60\%, 80\%, 100\%, $120 \%$ and $140 \%$ of maximum soil water retention capacity) and four replications.

Pots maximum soil water retention capacity was maintained by gravimetric method, according to the methodology described by reference [10].

Phosphorus and potassium basic fertilization was incorporated into the soil at planting. Following soil chemical analysis, $110 \mathrm{mg} \cdot \mathrm{dm}^{-3} \mathrm{P}_{2} \mathrm{O}_{5}$ and $50 \mathrm{mg} \cdot \mathrm{dm}^{-3} \mathrm{~K}_{2} \mathrm{O}$ were applied, using single superphosphate and potassium chloride as sources, respectively.

Cowpea seeds from BRS Nova Era cultivar were sown in the pots, and thinning was conducted at five days after emergence, leaving three plants per pot, which were grown for 50 days.

Was used in this study, the BR3267 strain (SEMIA 6462), which received authorization from the Ministry of Agriculture of Brazil for use as inoculant for cowpea [11]. Thus, BR3267 strain was grown on YMA culture medium for 24 hours under constant agitation at $100 \mathrm{rpm}$ [12]. Then, $5 \mathrm{~mL}$ of the bacterial broth were applied near plant root zone.

Aiming at plants establishment, all experimental plots were maintained at $80 \%$ maximum soil water retention capacity for 15 days after germination. After treatment application and availability stabilization of each treatment, two weightings of each plot were performed daily, in order to replace the water consumed by evapotranspiration, always in the early morning and late afternoon.

Thirty-five days after treatments implantation, the experiment was harvested. In order to assess nitrogen nutritional status, SPAD reading at harvest and shoot total nitrogen concentration and accumulation were conducted. Shoot nitrogen concentration was performed according to the method described by [13], through dried samples in air circulating oven at $65^{\circ} \mathrm{C} \pm 5^{\circ} \mathrm{C}$ and grounded in a Wiley mill with a $1 \mathrm{~mm}$ diameter sieve. Nodulation was 
determined through nodules and nodules dry matter counting.

Results were submitted to analysis of variance and regression test at $5 \%$ probability through Sisvar statistical program [14]. Number of nodules and nodules dry matter variables were transformed by $(\mathrm{X}+1)^{0.5}$.

\section{Results and Discussion}

Soil water availability affected all analyzed variables, confirming that soil water availability interferes with cowpea development.

SPAD reading is directly related to plant nutritional status assessment, since there is a positive correlation with leaves nitrogen concentration [6]. This was confirmed in this study, where there was positive and significant correlation at $1 \%$ significance level, with a correlation factor $(r)$ of 0.62 . These results corroborate with those described by [15], who obtained a high correlation $(r=0.91)$ between SPAD reading and nitrogen concentration of nitrogen in cowpea plant leaves.

The relation between nitrogen concentration and chlorophyll index was linear and positive (Figure 1). This behavior indicates that, as shoot nitrogen concentration increases, SPAD reading rises proportionately. This relation is mainly attributed to the fact that $50 \%$ to $70 \%$ of leaves total nitrogen leaves are part of enzymes that are associated with chloroplasts [16]. Similar results were described by references [15] [17] [18], while working with cowpea.

Both SPAD index and shoot nitrogen concentration assessments were adjusted linearly decreasing to the regression model, representing 0.1879 SPAD reading and $0.1012 \mathrm{~g} \cdot \mathrm{kg}^{-1}$ plant shoot nitrogen decrease to each $1 \%$ increase in water availability (Figure 2(a) and Figure 2(b)). This represents a reduction of $31 \%$ and $41 \%$, respectively, in the flooded treatment (140\% water availability) compared to the water deficit (40\%) treatment. Effects found in this study may be related to those that were reported by [19] in a similar study with capim-convert HD364 subjected to water availabilities, where the highest SPAD reading in the lowest study availability (20\%) was attributed to the dilution effect, as the highest SPAD reading was obtained in the treatment where the lowest shoot dry matter production occurred.

During this study conduction, yellowing and subsequent leaf senescence was visually observed in the flooded treatment, justifying the drastic decrease in SPAD reading and total nitrogen concentration by increases in soil water availability. This indicates cowpea susceptibility to flooding. Under these conditions, respiration and plant metabolism are reduced as a result of soil oxygen deficiency, causing symptoms that initially appear as withering and leaf chlorosis, heading to stem hypertrophy, morphological and anatomical changes, reduced growth and roots death [20] [21].

Note that in this study there was no nitrogen application in mineral form, and this nutrient was exclusively provided through soil organic matter mineralization and nitrogen biological fixation, which possibly was the biggest responsible for the crop nitrogen supply, since plants were inoculated with BR3267 strain, suitable for the crop.

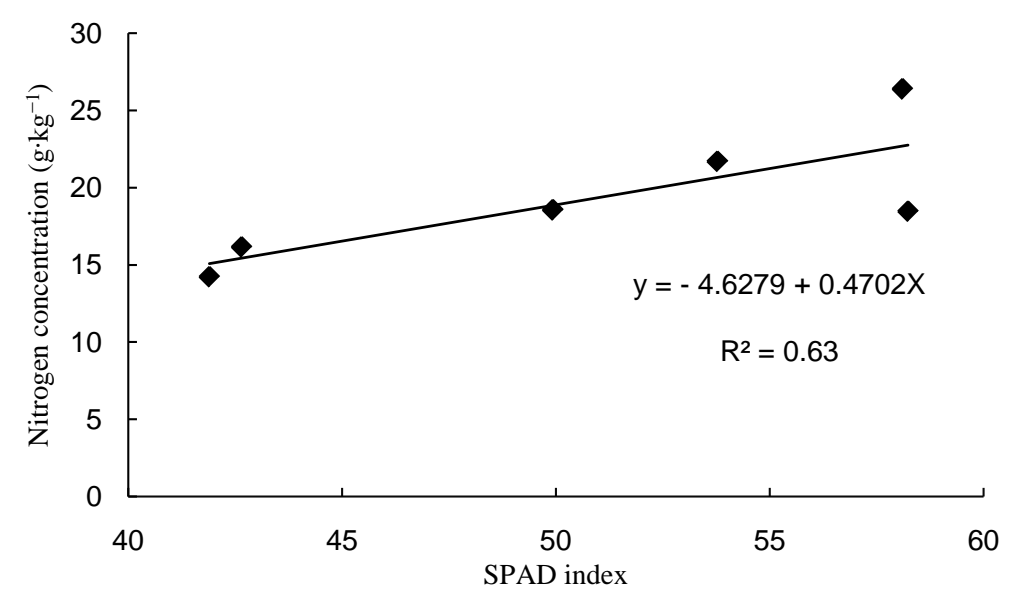

Figure 1. Relationship between shoot nitrogen concentration and SPAD reading of cowpea bean plants subjected to different water availabilities. 


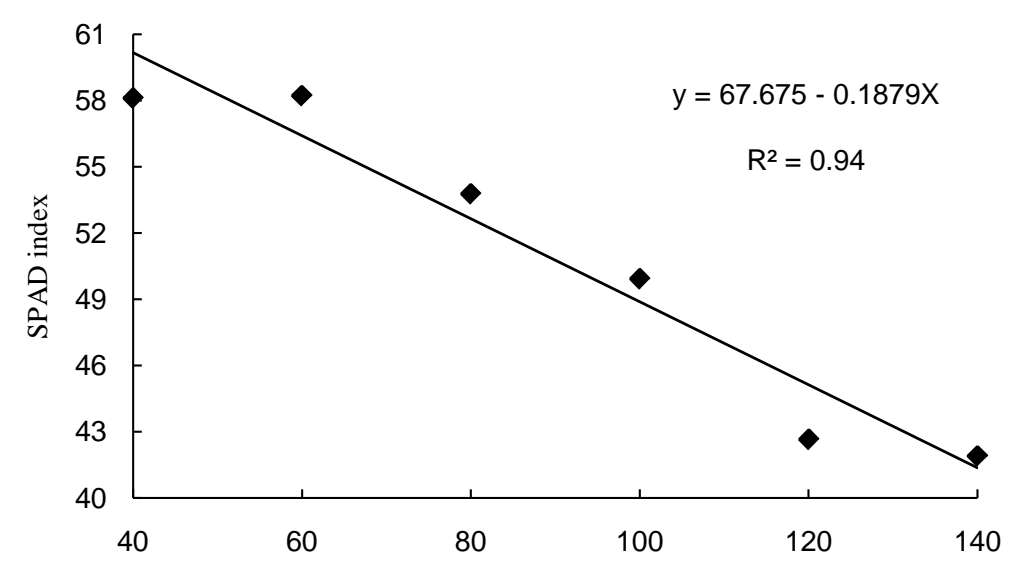

(a)

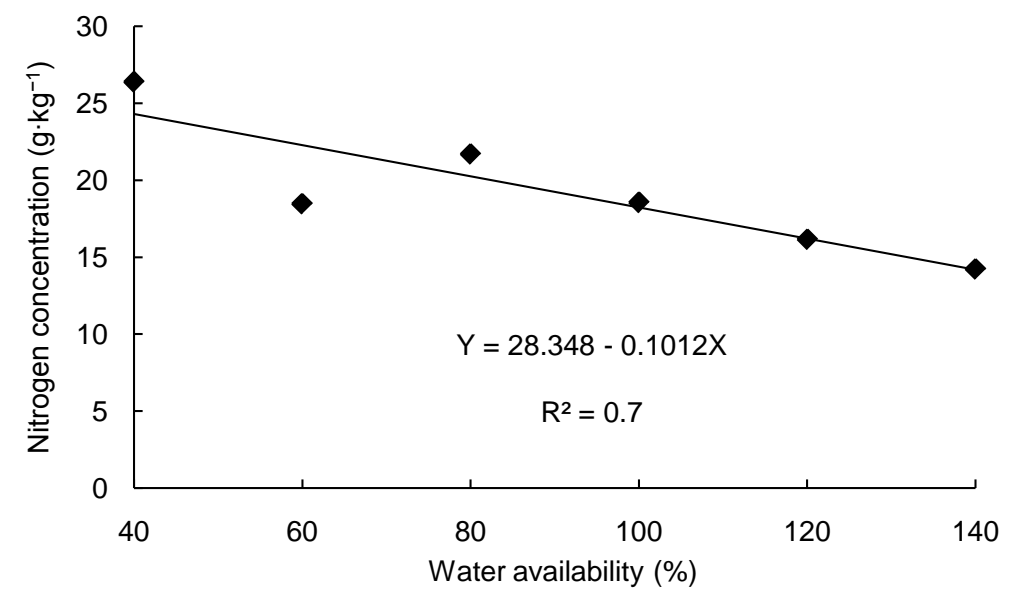

(b)

Figure 2. SPAD reading (a) and nitrogen concentration in cowpea plants subjected to water availabilities (b).

Considering nitrogen importance in plant development and fertilization absence, the SPAD reading and shoot nitrogen concentration linear reduction may have been a result of water excess in the root system, causing anoxia and/or hypoxia. These conditions are possibly unfavorable to the development of bacteria responsible for biological nitrogen fixation, which are aerobic.

Besides impairing plants vegetative growth, soil flooding can also reduce nodulation, and consequently, nitrogen symbiotic fixation [22]. This reduction has been mainly attributed to root nodules oxygen and $\mathrm{N}_{2}$ decrease [23] [24].

Under these conditions, nodule production is compromised, as observed in this study, where there was nodules dry matter and production reduction, adjusted to the quadratic regression model. Water availabilities that provided the highest yield and nodules dry matter were of $87.22 \%$ and $85.02 \%$, resulting in 145 nodules.pot ${ }^{-1}$ and $0.44 \mathrm{~g} \cdot$ pot $^{-1}$, respectively (Figure 3(a) and Figure 3(b)).

This decrease in the number of root nodules caused by soil flooding was previously observed in other studies [25]-[27]. According to reference [20], soil flooding causes significant reduction in rhizobium infection sites, thereby decreasing formed root nodules amount.

In a study performed by reference [28], where Bradyrhizobium strains inoculation was assessed in BRS Guariba cultivar cowpea plants under controlled conditions, using sterilized and with nutritive solution supply sand: vermiculite substrate $(2: 1, \mathrm{v} / \mathrm{v}), 220.78 \mathrm{mg}^{-p_{0}{ }^{-1}}$ accumulation was obtained with the BR 3567 strain, a lower result than what was obtained in the this study, where maximum accumulation was of $368.98 \mathrm{mg} \cdot \mathrm{pot}^{-1}$ in $78.76 \%$ maximum soil water retention capacity water availability (Figure 4). Visually it was observed differences in the color of the leaves as the size of the plants according to water availability (Figure 5). 


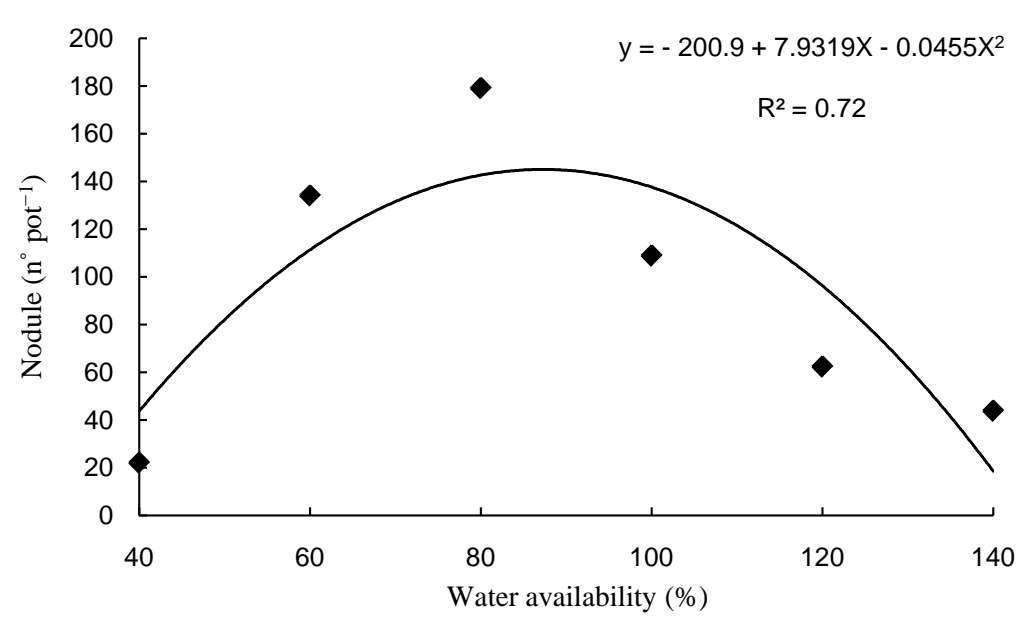

(a)

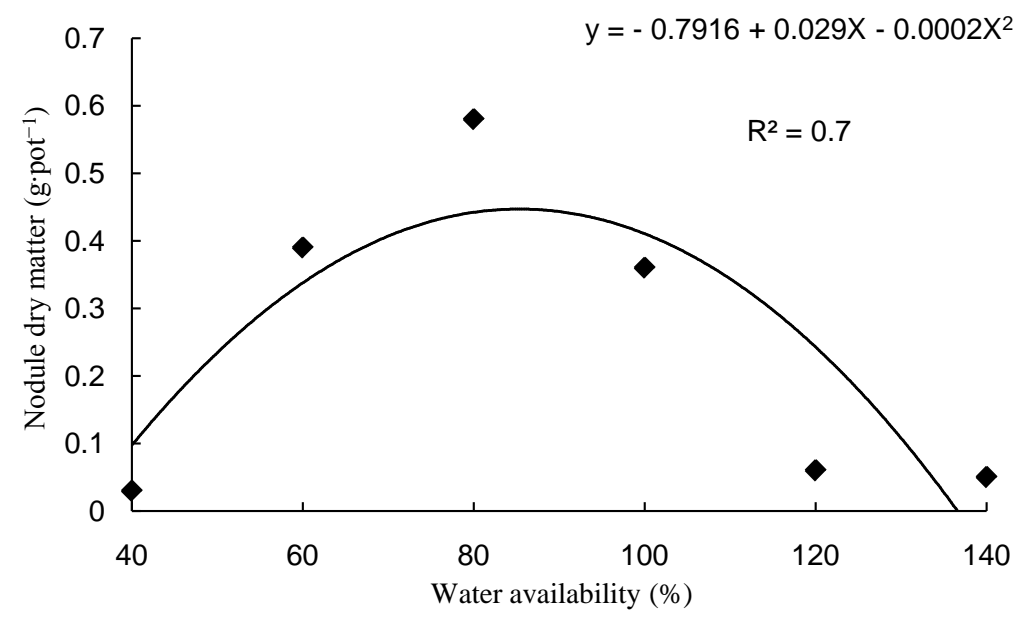

(b)

Figure 3. Number (a) and mass of nodules (b) of cowpea subjected to different water availabilities.

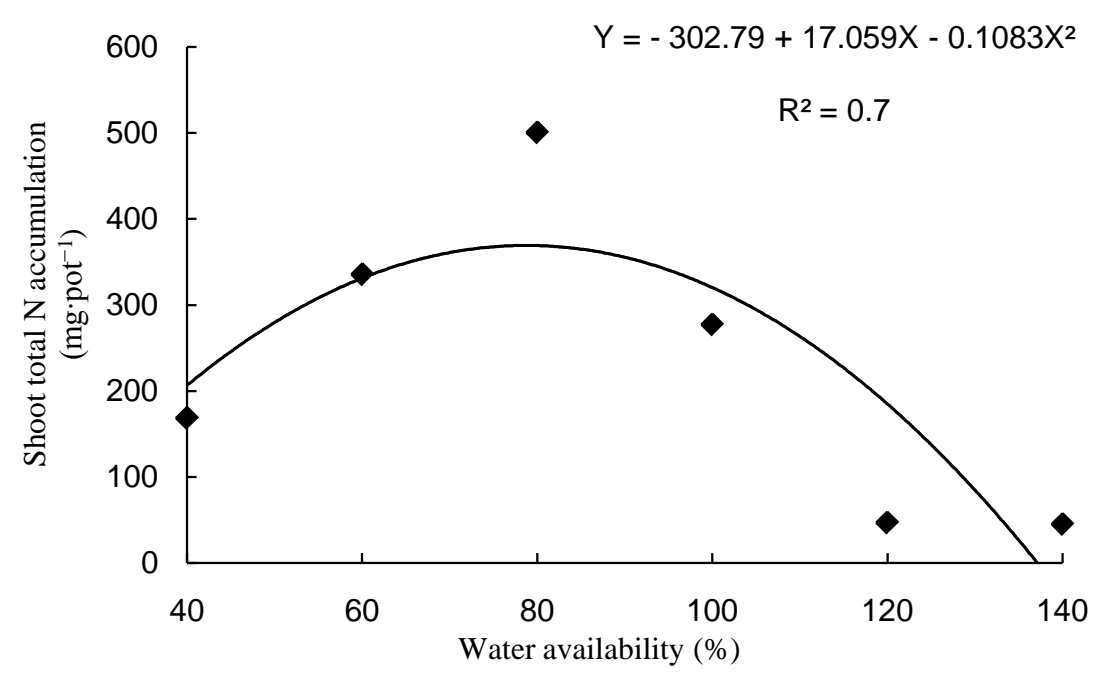

Figure 4. Shoot nitrogen accumulation of cowpea subjected to different water availabilities. 


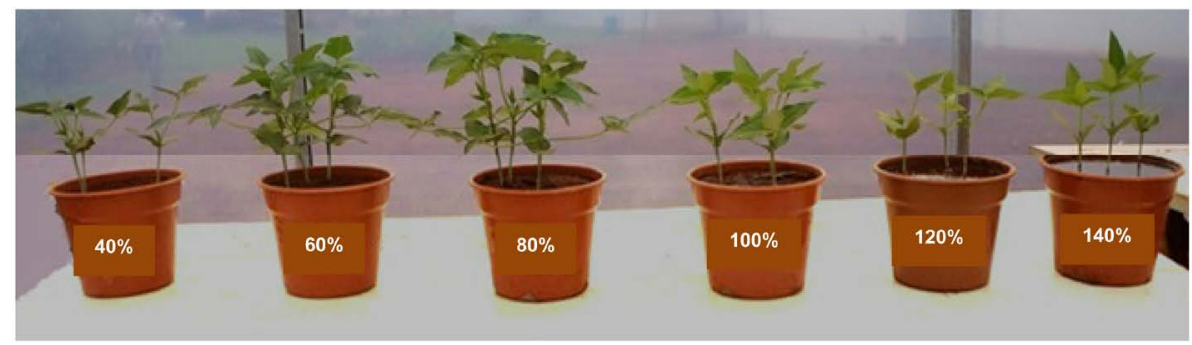

Figure 5. Growth curve of cowpea inoculated with rhizobia according of water availability soil.

This suggests that this study conditions enabled a better strain establishment, resulting in higher atmospheric nitrogen fixation, what allowed higher biomass production and this nutrient accumulation.

Alternatively to mineral fertilization, legumes use as green manure source is an important way to add nitrogen and cycle other soil nutrients, due to absorption and release that occurs in sync with plant needs [29].

Besides immediately available nitrogen via BNF, legumes use is favored by the low $\mathrm{C} / \mathrm{N}$ ratio. This is an aspect that, combined with soluble compounds large presence, favors its decomposition and mineralization, what enhances nutrient cycling, allowing residual effect for subsequent crops [30].

\section{Conclusions}

Water availabilities between $85 \%$ and $87 \%$ favor nodulation.

Nutritional status, assessed by SPAD reading and cowpea plants nitrogen concentration, is negatively affected by increased soil water availability.

Nitrogen accumulation and nodulation are increased by increasing soil water availability to the range of $78 \%$ $87 \%$, and soil water excess promotes more significant reductions to these attributes than deficit.

\section{References}

[1] Freire Filho, F.R., Lima, J.A.A. and Ribeiro, V.Q. (2005) Feijão caupi: Avanços tecnológicos. Embrapa, Brasília. http://www.agencia.cnptia.embrapa.br/Repositorio/cap6_000fm0xytbj02wyiv80kxlb3612vq547.pdf

[2] Monteiro, F.P.R. (2012) Impacto de herbicidas na nodulação e na produtividade do feijão caupi. Dissertação em Produção Vegetal, Universidade Federal do Tocantins, Gurupi. http://www.site.uft.edu.br/producaovegetal/dissertacoes/FABIO\%20PINTO\%20DOS\%20REIS\%20MONTEIRO.pdf

[3] Wendland, S.B., Portilho, I.I.R., Pierezan, L. and Mercante, F.M. (2010) Avaliação da nodulação e eficiência simbiótica em feijão caupi inoculado com rizóbios nativos de Mato Grosso do Sul. Cadernos de Agroecologia, 5, 1-5. http://ainfo.cnptia.embrapa.br/digital/bitstream/item/24203/1/Agroecologia17.pdf

[4] Martins, L.M.V., Xavier, G.R., Rumjanek, N.G., Rangel, F., Ribeiro, J.R.A. and Morgado, L.B. (2003) Contribuition of Biological Nitrogen Fixation to Cowpea: A Strategy for Improving Grain Yield in the Semi-Arid Region of Brazil. Biology and Fertility of Soils, 38, 333-339. http://dx.doi.org/10.1007/s00374-003-0668-4

[5] Zilli, J.E., Neto, M.L.S., Júnior, I.F., Perin, L. and Melo, A.R. (2011) Resposta do feijão caupi à inoculação com estirpes de Bradyrhizobium recomendadas para a soja. Revista Brasileira de Ciência do Solo, 35, 739-742. http://www.scielo.br/pdf/rbcs/v35n3/v35n3a09 http://dx.doi.org/10.1590/S0100-06832011000300009

[6] Lima, C.J.G.S., Oliveira, F.A., Medeiros, J.F., Oliveira, M.K.T. and Júnior, A.B.A. (2007) Resposta do feijão caupi a salinidade da água de irrigação. Revista Verde, 2, 79-86. http://www.gvaa.com.br/revista/index.php/RVADS/article/view/49/49

[7] Pires, J.L., Soprano, E. and Cassol, B. (2002) Adaptações morfofisiológicas da soja em solo inundado. Pesquisa Agropecuária Brasileira, 37, 41-50. http://dx.doi.org/10.1590/s0100-204x2002000100006

[8] Costa, R.C.L., Cardoso, B.B., Silva, J.T., Gomes Filho, J.G.F. and Silveira, J.A.G. (1996) O estresse hídrico diminui intensamente a assimilação do nitrato e a nodulação em feijão-de-corda (Vigna unguiculata, (L.) Walp.). Reunião Nacional de Pesquisa de Caupi, 4, 78-79.

[9] Claessen, M.E.C. (1997) Manual de métodos de análise de Solo. Empresa Brasileira de Pesquisa Agropecuária, Rio de Janeiro.

http://www.agencia.cnptia.embrapa.br/Repositorio/Manual+de+Metodos_000fzvhotqk02wx5ok0q43a0ram31wtr.pdf 
[10] Bonfim-Silva, E.M., Silva, T.J.A., Cabral, C.E.A., Kroth, B.E. and Rezende, D. (2011) Desenvolvimento inicial de gramíneas submetidas ao estresse hídrico. Revista Caatinga, 24, 180-186.

[11] Rumjanek, N.G., Xavier, G.R., Martins, L.M., Morgado, L.B. and Neves, M.C.P. (2006) Feijão caupi tem uma nova estirpe de rizóbio, BR3267, recomendada como inoculante. Embrapa Agrobiologia, Seropédica. (Embrapa Agrobiologia. Boletim de Pesquisa e Desenvolvimento, 15). http://www.infoteca.cnptia.embrapa.br/infoteca/bitstream/doc/629225/1/bot015.pdf

[12] Döbereiner, J., Baldani, V.L.D. and Baldani, J.I. (1995) Como isolar e identificar bactérias diazotróficas de plantas não-leguminosas. Embrapa-SPI, Brasília.

[13] Malavolta, E., Vitti, G.C. and Oliveira, S.A. (1997) Avaliação do estado nutricional das plantas: Princípios e aplicações. Potafos, Piracicaba. http://www.pldlivros.com.br/MaisProduto.asp?Produto=37

[14] Ferreira, D.F. (2011) Sisvar: A Computer Statistical Analysis System. Ciência e Agrotecnologia, 35, 1039-1042.

[15] Morais, R.R., Fontes, J.R.A. and Gonçalves, J.R.P. (2013) Estimativa dos teores de nutrientes foliares em feijão caupi utilizando clorofilômetro. Embrapa Amazônia Ocidental, Manaus. (Embrapa Amazônia Ocidental. Circular Técnica, 40). http://ainfo.cnptia.embrapa.br/digital/bitstream/item/88776/1/Circ-Tec-40.pdf

[16] Chapman, S.C. and Barreto, H.J. (1997) Using a Chlorophyll Meter to Estimate Specific Leaf Nitrogen of Tropical Maize during Vegetative Growth. Agronomy Journal, 89, 557-562. http://dx.doi.org/10.2134/agronj1997.00021962008900040004x

[17] Carvalho, M.A.C., Furlani Junior, E., Arf, O., Sá, M.E., Paulino, H.B. and Buzetti, S. (2003) Doses e épocas de aplicação de nitrogênio e teores foliares deste nutriente e de clorofila em feijoeiro. Revista Brasileira de Ciência do Solo, 27, 445-450. http://dx.doi.org/10.1590/S0100-06832003000300006

[18] Sant'ana, E.V.P., Santos, S.B. and Silveira, P.M. (2010) Adubação nitrogenada na produtividade, leitura SPAD e teor de nitrogênio em folhas de feijoeiro. Pesquisa Agropecuária Tropical, 40, 491-496. http://www.alice.cnptia.embrapa.br/alice/bitstream/doc/874592/1/6320503921PB1.pdf http://dx.doi.org/10.1590/S1983-40632010000400012

[19] Bonfim-Silva, E.M., Silva, M.C., Schlichting, A.F., Porto, R.A., Silva, T.J.A. and Koetz, M. (2014) Desenvolvimento e produção de capim-convert HD364 submetido ao estresse hídrico. Revista Agro@mbiente, 8, 134-141. http://revista.ufrr.br/index.php/agroambiente/article/view/1437

[20] Bradford, K.J. and Yang, S.F. (1981) Physiological Responses of Plants to Waterlogging. HortScience, 16, 25-30.

[21] Kramer, P.J. (1983) Water Relations of Plants. New York Academic Press, New York. http://www.sciencedirect.com/science/book/9780124250406

[22] Zhang, F. and Smith, D.L. (2002) Interorganismal Signaling in Suboptimum Environments: The Legume-Rhizobia Symbiosis. Advances in Agronomy, 76, 125-161.

[23] Shiferaw, W., Shelton, H.M. and So, H.B. (1992) Tolerance of Some Subtropical Pasture Legumes to Waterlogging. Tropical Grasslands, 26, 187-195.

http://www.tropicalgrasslands.asn.au/Tropical\%20Grasslands\%20Journal\%20archive/PDFs/Vol_26_1992/Vol_26_03_ 92_pp187_195.pdf

[24] Arrese-Igor, C., Royuela, M., Lourenzo, D., Felipe, M.R. and Aparicio-Tejo, P.M. (1993) Effect of Low Rizhosphere Oxygen on Growth Nitrogen Fixation and Nodule Morphology. Physiologia Plantarum, 89, 55-63. http://dx.doi.org/10.1111/j.1399-3054.1993.tb01786.x

[25] James, E.K. and Crawford, R.M.M. (1998) Effect of Oxygen Availability on Nitrogen Fixation by Two Lotus Species under Flooded Conditions. Journal Experimental Botany, 49, 599-609. http://dx.doi.org/10.1093/jxb/49.320.599

[26] Vignolio, O.R. and Fernández, O.N. (1999) Flooding Tolerance in Five Populations of Lotus glaber Mill. (Syn. Lotus tenuis Waldst. Et. Kit). Australian Journal of Agricultural Research, 50, 555-559. http://dx.doi.org/10.1071/A98112

[27] Scholles, D. and Vargas, L.K. (2004) Viabilidade da inoculação de soja com estirpes de Bradyrhizobium em solo inundado. Revista Brasileira de Ciência do Solo, 28, 973-979. http://dx.doi.org/10.1590/S0100-06832004000600005

[28] Zilli, J.E., Neto, M.L.S., Júnior, I.F., Perin, L. and Melo, A.R. (2011) Resposta do feijão caupi à inoculação com estirpes de Bradyrhizobium recomendadas para a soja. Revista Brasileira de Ciência do Solo, 35, 739-742. http://dx.doi.org/10.1590/S0100-06832011000300009

[29] Torres, J.L.R., Pereira, M.G. and Fabian, A.J. (2008) Produção de fitomassa por plantas de cobertura e mineralização de seus resíduos em plantio direto. Pesquisa Agropecuária Brasileira, 3, 421-428. http://dx.doi.org/10.1590/S0100-204X2008000300018

[30] Silva, E.C., Muraoka, T., Buzetti, S., Veloso, M.E.C. and Trivelin, P.C.O. (2006) Absorção de nitrogênio nativo do solo pelo milho sob plantio direto em sucessão a plantas de cobertura. Revista Brasileira de Ciência do Solo, 30, 723732. http://dx.doi.org/10.1590/S0100-06832006000400013 